\title{
The relevance of dietetics in Gandhian philosophy: Mapping the trajectories of his experiments
}

\section{Debashish Mitra}

ABSTRACT: This article argues for analytics of dietary habits of Mahatma Gandhi through an argument around his practices and manner of articulation on discourses on food; his experimentation around dietetics and its relation to political goals in the light of colonial governmentality. Gandhi's dietetics practice intervened with the construction of Oriental as the 'others', showing that the subject (Indian) domain constituted the hegemonic order of colonial reign by presenting the superiority inherent in the colonial culture. In this regard, this article describes the emergence of Gandhi's alternative dietary habits, with analyses of discourses on scientific treatment of food as a part of daily livelihood, while understanding and arguing for the importance of dietetics as an integral part of the political world of modernity. It concludes that the broader contours of Gandhian philosophy and its introduction in Indian society through nationalist politics are uniformly appended with the formulation of his experimentation, not only with his philosophical and political goals but also with his daily practices dietetics constitute an essential part. Throughout, there is an attempt to present the symbolic and discursive construction of dietetics and experimentations to negotiate the individual's character.

Keywords: dietetics, experiments, Gandhi, Ahimsa, vegetarian 


\section{Introduction}

The broad contours of Mohandas Gandhi's (hereafter Gandhi) ${ }^{\mathrm{i}}$ philosophies are connected with his everyday life practices, dietetics being a prime component. His ideas of diet and food habits were not hermetically modelled but represented a collective action to achieve truth and brahmacharya in his personal space and attain Swaraj in the public space. According to Gandhi, these words were significant from an administrative or political point of view and constituted an integral part of life, encompassing every sphere, including morality, truth in action and deeds, sexuality, economic improvement, and women empowerment. Gandhi's dietary debates went through various discursive shifts throughout his life, just as his politics and philosophy evolved into new dimensions. Critically probing and expanding the original frameworks of Gandhian ideas facilitates expanding the conceptual space of Gandhian practices regarding dietetics.

To understand the discourses on Gandhian dietetics, one must begin with his practices' distinct, transparent world. The vastness of the literature on Gandhian philosophy points to the manifold nature of Gandhian practices and concepts implicit in these practices, in their clear and often distinct logic and more conceptually detailed renderings. Popularly known as the spiritual theory of 'Truth' offered by Gandhi, this forms the starting point for any critical exploration. As illustrated in this article, the Gandhian practices and their openness to a consistent political understanding underscore dietetics and other essential parts of his life. All social practices of Gandhi, whether based on ritual norms reinforcing hierarchical relations; transactional strategies arranged around a central and dominant philosophy; moral practices and disciplinary power fabricating subjects or practical life-relations and economics, are all discursive components. Constituted symbolically, they determine the subject positions and construct an agent as the locus point for many a discourse within an overall expansive formation/framework. The idea of dietetics is situated at the intersection of this manifold — sometimes reinforcing, at other times antagonistic — set of debates on a philosophical level that is intrinsically embedded within his political relations. 
Dietetics formed an essential chapter in Gandhi's life, which in many ways, along with his politics, was bound by the norms of spirituality, doing his experiments with diet, no exceptions. Gandhi believed that to evolve spiritually and attain the universal truth, one must be mindful of eating. Some scholars (Slate 2019) felt that he failed to use his diet idea or precise his dietary experiments to bring Swaraj to every Indian. In this context, it is worth remembering that Gandhi never imposed his food ideas publicly, except for disciples in his ashrams, but kept the experiment with himself. His ideas of diets and food habits were not exclusive domains of his life but an intrinsic part of the collective action that he set to achieve personally (truth) and publicly (Swaraj) as a form of moral, philosophical and political guidance. He maintained that food is the vital cog in the wheel for one who cannot escape the clutches of the physicians due to his inability to control the senses of the tongue, in turn, becomes "the slave of his body instead of remaining its master, loses self-control, and ceases to be a man." (Gandhi 2012: 249)

This article identifies the thought processes and reasons for his experimentation with ideas regarding food and dietary habits. It is pertinent because "the kinds of questions Gandhi asked nearly eight decades ago are the ones which now face both the underdeveloped and the post-industrial societies caught up in a deep upsurge of confusion and disillusionment." (Sethi 1979: 3) These questions can be answered if the underlying thoughts and practices of Gandhi's daily life are identified and scrutinised to understand the evils of our times.

Hence, control over food habits, which Gandhi referred to as 'control over palate', constitutes a crucial aspect among all the sensory organs. Without it, the order of internalisation, thereby achieving the most significant objective, cannot be realised as the question of choosing one's diet was inexorably tied with an individual's political belief. The article first discusses his dietary and food habits to understand the relationship between diet and belief systems. It then seeks to understand the experimentations of Gandhi's dietary habits as the basis of his own philosophical and political ideas. Finally, the analysis seeks to identify how the components mentioned above are intricately linked to 
form a suitable body of knowledge in Gandhian dietetics, which is still relevant in this ruthless and competitive global scenario of human existence.

\section{Dietetics as the Core Idea of Gandhian Philosophy}

Ahimsa $^{i i}$ remains one of the essential edifices of Gandhi's philosophy and politics. However, many may argue that he missed the critical character of enquiry, human control over the natural world, and feasibility and capability in the real world. This critical posture would imply "an absence of a particular 'spiritual dimension' in the practical world that Gandhi seems to have missed." (Parekh 1997: 35) However, Gandhi's focus was on the entirety of applying his philosophical and moral objectives and not its limited political application. His denunciation of violence centred on bodily and mental stimulation as his refusal of violence obtained, and primarily began, from its control over sensory organs. It is the truth (in his words Satya) that Gandhi considered the ultimate destiny of man's life, which can be achieved through Ahimsa, Satyagraha. ${ }^{\text {iii }}$

Like ahimsa, much of his philosophy pivoted around the cardinal belief that rituals in our daily lives help achieve the highest body of knowledge, i.e., truth. Those daily and simple rituals are the stepping stones to access the objectivity of truth. All these are interrelated and produce the Gandhian thought process or belief system, where each one is complementary to the other and interconnected. One cannot and must not try to compartmentalise and segregate the thought process for individual internalisation because one cannot achieve the highest form of realisation of one's life by treating them as distinct and exclusive. Gandhi himself stated that "Ahimsa and Truth are so intertwined that it is practically impossible to disentangle and separate them." (Tikedar 1971: 5) The realisation of truth, which is the realisation of oneness with all that is created as an extension of oneself, portrays ahimsa, whereas ahimsa, when adopted to realise the absolute truth, becomes an effective spiritual practice. This spiritual practice can be possible only when one situates one's life with the daily rituals of livelihood. Hence, to practise ahimsa, one does not need to be a rishi (saint). Gandhi (1920) said that ahimsa is meant for ordinary people as well. Hence, the corollary relation among his ideas can be 
established in ascending order as follows: practice/experimentation of daily rituals in private space practice/experimentation of philosophical and political ideas, like, Ahimsa, Satyagraha; achieving Satya (truth) as the final destination and all these domains are interrelated and enmeshed. The objective of achieving truth is not possible unless one celebrates the other two practices and experimentations. Gandhi's philosophical and political practices, however, are widely discussed or dissected areas. For instance, as Banerjee (2020: 90) notes, "Gandhi came to the conclusion that while the end is satya, ahimsa is the means; while duty is satya, rights belong to ahimsa; while give is satya, take is ahimsa." Similarly, by inquiring into his daily livelihood rituals, we have chosen to situate ourselves concerning dietetics and enter into a dialogue with Gandhi, often regarded as 'irrelevant' by academia and seen only as a concern of the modern world.

The narrative of food consumption began with Gandhi's concern for his bodily activity and the people who surrounded him. With the initiation of public activity, he became aware of the people's well-being and considered it his responsibility. As a critique of modern western civilisation, he did not believe in medicinal treatment or drugs to cure physiological ailments. He even preferred to view the term 'disease' as dis-ease or an individual whose physical or mental state of affair is not at ease or comfort, where dis implies negation. Gandhi often referred to naturopathy as a hobby, preferring that over allopathy or other medics like vaidyas or hakims arguing that nature should be able to rectify any disease caused by breaking the law of nature. ${ }^{\text {iv }}$ He was mostly convinced that disease is a rupture in the body system, part of nature. Hence to maintain or help nature overcome this break in the system, we must have a proper diet (Gandhi 1949: 2).

Throughout his life, Gandhi's dietary debates went through various discursive shifts. What remains unswerving throughout, though, is the existence of an element of resistance to modern civilisation, which he thinks is inimical to all our pain and sorrows (the idea he cultivated through the constant questioning of his presuppositions), for which he focused his dietetic thoughts or experiments into three most important monographs (Gandhi 1948; 1949; 1959) and several other references in his 
autobiography (Gandhi 1927). Nevertheless, the monographs primarily dealt with the nutritional and hygienic aspects of the diet, whereas the autobiography concentrated upon his regular experimentations to reach certain political goal/s. For instance, "having thus set forth their object and the train of ideas which led up to them. I now propose to describe the dietetic experiments at some length." (Gandhi 1927: 295-6)

His diet analyses experienced a wide range of stages, particularly during his time as a practitioner and student of law in London and when he changed from being an advocate of eating meat to an active campaigner for vegetarianism. His experiments were not limited to food items alone but also involved the equipment or utensils used for cooking. For instance, in Chapters 3 to 7 of Young India, ${ }^{v}$ he prescribed the oven, vessels for cooking, and even the amount of water to be used for cooking. In brief, and in the true sense, a complete procedure of his dietetics involved producing the food, the nutritional value of the raw or finished food item, and the meagre resources of the production, which aided in producing the food. Hence, we concentrate on all his publications mentioned above to understand the long-term trajectory of Gandhi's broader discourse of nationalism and social reform through dietetics.

Gandhi shunned milk for six years of his life on ethical grounds arguing that milk was as much a non-vegetarian product as an egg, arguing that a man was entitled only to his mother's milk, and expressed an urgent need to find a scientific alternative to milk and meat from vegetarian sources. Perhaps Gandhi failed to realise (or write about it) that the milk industry had unpalatable consequences regarding beef being an unwanted by-product. However, Gandhi (1957) did outline his food preferences, the logic behind such choices, and his scientific analysis of such choices. According to him, food taste was acquired, not something we are born with. Hence, it is debatable whether Gandhi could easily be called a modern-day vegan, keeping the hierarchies and differentiation among different types of vegans, like health vegans or ethical vegans (Greenebaum 2012).

\section{Dietetic Experiments in Early Stages of Gandhi's Life}


Although born in a strict vegetarian Gujarati Baniya ${ }^{\mathrm{vi}}$ family, Gandhi was not averse to non-vegetarian food during his college days in Rajkot, then amid a wave of reforms where meat-eating was regarded as a symbol of progress. A friend of Gandhi's brother, Sheikh Mehtab, prodded him into eating meat. Forwarding a logic where meat-eating was synonymous with being strong and weakness in physique was related to vegetarianism. Even in contemporary studies (Lax \& Angela 2020; Rothgerber, 2013; Ruby \& Heine, 2011), masculinity and modernity are connected with consuming meat or being nonvegans. In his earlier days, Gandhi began believing that if the whole country took to meat-eating, the British colonial rule could be trounced. It is often said that we are what we eat. Gandhi denied and transgressed his caste affiliation in consuming meat and indirectly went a step forward acquiring a pan-Indian identity - a new self-identity necessary for being a national leader. However, this previously held point of view changed when he was confronted with contrary evidence (both in London and South Africa) about dietetics and this willingness to change emphatically set Gandhi apart from other politicians of his time.

Gandhi's views on vegetarianism took a concrete shape in his writings in the journal The Vegetarian. To strengthen the cause of vegetarianism, Gandhi gave the example of Indian shepherds who were as strong as a meat-eating European. Gandhi wrote: 'An Indian shepherd is a firmly built man of Herculean constitution' (CWMG Vol.1: 24). In another article, he reflected on the effects of colonial rule on the Indian diet (CWMG Vol.1:22). He pointed out that killing a 'life-to be' was unethical as killing an animal for food, hinting at eggs and milk. While interacting with the vegetarian community of England, Gandhi coined the term 'Other West', and for him, peaceful coexistence was possible between the East and the Other West. Gandhi's experimentation in forms of practices for vegetarianism honed his leadership skill in later days.

During Gandhi's voyage to London to study law, he vowed to his mother to refrain from three objects (sex, wine and meat) in England. Even in his long journey on the ship, Gandhi shunned nonvegetarian food, keeping his mother's wishes. In London, Gandhi's ideas went for a toss as he 
delineated the concept of masculinity from the practice of meat-eating by constantly engaging with his colleagues and critics (consider in this regard Gandhi's view on race, caste, and gender, which changed in due course of time). In his way, Gandhi challenged the colonial formulation of tradition and modernity and returned to his cultural moorings in dietary habits. Discovering a new sense of self, Gandhi sought to use vegetarianism to symbolise resistance against the West and everything associated with it.

From a believer ${ }^{\mathrm{vii}}$ in eating meat to overthrowing the colonial rule, Gandhi's experiment with dietetics started with an active campaign for vegetarianism associated with the London Vegetarian Society ${ }^{\text {viii }}$. He elaborated on how Henry Salt's book Plea for Vegetarianism, Howard William's The Ethics of Diet and Dr Anna Kingsford's The Perfect Way in Diet had motivated him to begin his experiments in dietetics, which ultimately moved to religion). The society and later the club he founded for vegan development demonstrated more extensive difficulties to an assortment of normative social practices he followed later. Brown (1996: 2) indicated that Gandhi's work as a member of the society inculcated a combined diet, health, and religious approach that remained forever with him. He had recognised the influence of this formative period of his life in England as the most crucial part and would remain 'indebted to the West' (Gandhi 1955: 2) for changing the course of his dietary philosophy. His active involvement remained mainly at the Central Restaurant of London for proper vegetarian meals regularly, owing to his vow to his mother while at London, while practising and studying as a student of law and accumulating ideas of the British cultural identity ${ }^{\text {ix }}$. He was so involved with the approach that he started preaching the ideas from door-to-door of the British Society in London and other members of the society.

At the Central Restaurant, Gandhi laid his hand on Henry Salt's book, Plea for Vegetarianism (1886), which had a lifelong impact on Gandhi's philosophy of taste and food. After reading it, Gandhi became a vegetarian by choice and not merely one bound by customs and traditions. He was embracing the principles of renunciation, self-control and spiritual evolution embedded in such voluntary choice. 
Salt (1886) advocated vegetarianism for its economic, scientific, moral, aesthetic, physical and utilitarian perspectives and forwarded examples of great writers like P. B. Shelly and Bernard Shaw, who were complete vegetarians. He believed vegetarianism was the future of the world. In London, Gandhi shared a room with Josiah Oldfield, who studied to be a doctor and was an active member of the London Vegetarian Society. Oldfield edited the journal of society and wrote on diet and politics. Gandhi and Oldfield served lentil soup, boiled rice and large raisins for friends coming over to their home. In brief, Gandhi spread vegetarianism in his battle, arguing for a steadfast moral commitment to the cause, subscribing to the journal, and becoming an Executive Committee member of the society. He regularly wrote for the journal and travelled to hold public meetings and gatherings for the cause. In a sense, these were Gandhi's first lessons in public speaking, writing and organising a public forum, discovering yet again a new self, which could work for a public cause.

Cultural and counter-cultural axioms exist in such a narrative, which many tried to view as constructing a latent form of anti-thesis to that of the present hegemonic thesis of English cultural Society (May 1972: 112). His anti-thesis existed in the dietetics only, to which many critics argued that his embracing of partial markers (dietetics) ignoring the others (language, dress codes, attitudinal preferences). It seemed inconsistent when he became a vocal critic against the class of Indian National Congress (INC) members who remained within the trope of modern British cultural identities while representing the poor and marginalised Indian subjects ${ }^{\mathrm{x}}$. Nonetheless, refusing to eat meat in the British cultural space was a form of resistance and a mark of social action, culminating in his long political sojourn in India. This experiment acted as a practice board to prepare his social activities in public spaces. While for Gandhi, South Africa remained an arena to practise his political activity in public spaces, dietetics became a space for individual experimentation.

At Tolstoy Farm in South Africa, Gandhi mostly consumed raw food and advised the residents to produce it themselves, encouraging untreated vegetables and fruits. Gandhi's preference for cereals, exceptionally unpolished wheat, with fibres providing roughage, adhere to modern-day nutrition 
fundamentals of anything polished detrimental to gut health. With all enthusiasm for seasonal fruits, Gandhi mentioned an ideal breakfast comprising fruit and milk. He also highlighted the importance of natural sugar present in fruits.

Later in life, he would go for several days without preparing his food. During the summer of 1893, Gandhi consumed raw food for 11 days at a stretch, about which he maintained a food diary that remarkably recorded everything he consumed and felt essential to keep the body alive and moving ${ }^{\mathrm{xi}}$. Gandhi's affinity towards raw food had several reasons, which he often explained. Apart from simplicity, cleanliness, and nutritional value, raw food had immense importance to cleanse the body of its impurities. In this assertion, Gandhi challenged the assumptions of Strauss (cited in Counihan \& Esterik, 2013) that cooked food was akin to culture and raw was in opposition to civilisation. To Gandhi, however, raw food was liberating at various planes, economic as well as social. He believed money and time saved from cooking would open up a path for a better life for the poor. ${ }^{\text {xii }}$ Slate (2019) identified that Gandhi was one rare species of activist who tried to liberate every Indian. Gandhi opposed a system in which women were forced to cook and underlined that a kitchen should be a place for joyful creation and partly aimed to enable women to be free from the kitchen.

Gandhi's South African experience marked the beginning of a new phase in the evolution of his philosophy of dietetics. During his 21 year-long stays, Gandhi became a political activist, pursuing his altruistic activism for vegetarianism unabated. In letters to Indian students in England, he advised them to join The Vegetarian Society in London. In his 'London Diary', Gandhi wrote about dietetics to guide Indian students to England for higher studies; he devoted 20 out of 55 pages motivating the students to remain vegetarian.

Another instance of his dietetics activism reinforcing his philosophic activism became evident when he sought to eliminate milk from his daily diet, to which Henry Kallenbach was a vital companion and advisor. Upon Kallenbach's advice, he abjured milk and "decided to live on a pure fruit diet." (Gandhi 1927: 302) Food preparation was wholly done away with raw groundnuts, bananas, 
dates, lemons, and olive oil comprised of his regular diet. This systematic approach to the diet is closely connected to his philosophy of brahmacharya due to his cardinal principle regarding food as a vital component shaping human cognisance. Roy (2002) identified that his early experiments not only portrayed a construction of the self, different from the western dietary trends and culture, but also as a part of his practice of brahmacharya by controlling the palate and forming a pure body analogous to the Indian philosophic principles of having a clean, pure and sattvic body. Thus, his practices and ways of thinking did not disengage from Satyagraha and his political philosophies, but they were naturally associated. At one point, he discussed what he called 'domestic satyagraha' (Gandhi 1925: 249). After his first jail experience in 1908, there came an occasion that compelled him to give up salt altogether, which he continued to follow for ten years. It so happened that his wife, Kasturba, had begun haemorrhaging after a brief respite following an operation. Since all remedies had failed, Gandhi tried to convince her to give up salt and pulses. Kasturba would disagree and instead challenged Gandhi himself to give up these items. A determined Gandhi announced that he would give up the items for one year, whether Kasturba followed his advice or not. Hearing this, Kasturba readily agreed to abstain from these articles and quickly got better after that. Many such narratives in his daily rituals became a part of the thesis we are trying to develop here.

\section{Experiments after Arrival in India}

Back in India, fasting became a common form of protest for Gandhi. He did public fasting more than a dozen times, the longest covering 21 days. Fasting, an extension of vegetarianism, a practice of selfcontrol and renunciation of pleasure, involved renunciation and self-control. Vegetarianism, like ahimsa, was a voluntary weapon of struggle since one had to actively and affirmatively choose to follow his choice. Gandhi's vegetarianism started him on the road to ahimsa, as to him, there was inherent violence in eating meat and a nascent non-violence in abjuring it.

Gandhi, who believed strongly in a milk-free and salt-free diet, changed his course of action for social and purposive actions. He persistently avoided salt in his food, as he thought the natural 
ingredients of his early dietetics (around 1911) had enough salt substitute. In a letter to a friend ${ }^{\text {xiii }}$, he wrote:

"Doctor friends have always told me that I should not go without salt. I thought it was better that the skin should be a little rough, in case I had to go to France or Mesopotamia, and with this idea I started taking salt. This brought on diarrhoea. I should have taken this as a warning that I should stop eating, but I fasted only partially. The result was acute dysentery. In this disease, food is like poison; despite that, I continued to eat. Thus, I have had to pay for my lack of self-control."

Around late 1920, after several suggestions and explanations from his doctors, he reluctantly welcomed $30 \mathrm{gm}$ of salt in his diet. "After understanding the importance of salt-particularly for those working in the fields-Gandhi went on to protest Britain's hefty tax that made salt virtually unattainable for poor people in India", which is regarded as the crucial turn in Indian colonial resistance and also his disobedience of colonial authority ${ }^{\mathrm{xiv}}$. This incident came to be known as the Salt March in 1930, one of the landmark events in India's national movement, accompanied by 60,000 satyagrahis. Similarly, he also started consuming goat milk after a terrible bout of dysentery in 1917. On another instance, during a religious festival at his ashram, Gandhi overindulged in eating and within an hour came down with acute dysentery:

"all a-tremble, I broke the fast and brought great trouble on myself. Nor did I exercise self-restraint in deciding what to eat; I ate ghens [a semi-liquid rice preparation]. If I had taken vegetable soup only, the painful result would certainly not have followed. Today I am too weak to get up or walk. I have almost to crawl to reach the lavatory and I have such griping pain there that I feel like screaming. ... I am sure my pain will subside at a quarter to six. If I committed an error in eating, it is no excessive punishment to suffer for 24 hours. And the punishment will be so short because I have fasted today. Don't worry on my account. I believe by tomorrow I shall be completely free from the pain at any rate. If I am not careless in diet, I shall be my normal self in three or four days." (Gandhi to Fulchand Shah, 12 August 1918)

These two incidents depicted that all his experiments in dietetics directed towards moral and political actions could be suitably amended or altered if those 'mean' could justify the 'end'. The basis 
of Gandhi's moral actions rests on his recognition that health is not the monopoly of vegetarians. Many non-vegetarians keep good health, while on the other hand, many vegetarians opt for vegetarianism to resolve all fundamental problems, but their extreme fetish of cheese, lentils and haricot beans also have a profound negative effect on their health. It should also be noted that most vegetarians were compelled to adopt vegan food habits because of disease or any other health-related aspect, and they are most likely to revert to non-vegetarianism. Gandhi believed that the cause of diseases could be excessive eating, too frequent meals, and over-indulgence of concentrated starch and sugar. He suggested "avoiding sweets as much as possible and consuming Gur (jaggery) in small quantities and even disliked polishing rice or refining wheat flour. Irrespective of the nature of the diet, Gandhi added that it is the palate's control, which is most important. Thus, to keep healthy, no matter what you eat, it is necessary to cut down on the quantity of food and reduce the number of meals." (Gandhi 1949: 14)

As Gandhi's philosophy of Swaraj, or self-rule, began to gain an ever more sophisticated definition, he became increasingly disinterested in the question of physical strength. Mental fortitude was paramount in his schema of things, harnessed by discipline, prayer, and compassion. Food was one such vehicle to achieve the desired objective-it was a supplier of nutrients rather than a source of flavour, tastes and pleasure. For years, his body has endured such discipline. During his political campaigns from 1913 to 1948, he walked several kilometres. Yet, he struggled with several health issues like pleurisy (1914), malaria (1925, 1936 and 1944), gastric flu (1939) and influenza (1945). He was operated on for piles (1919) and severe appendicitis (1924) (Bhargava \& Kant 2019). However, he was back on his feet every time, primarily due to his disciplined lifestyle, focusing on physical fitness and a balanced diet. In a series of letters, he wrote that he deserved the retribution of the illness because of his excessive intake of delicious food during his illness. At this time, he was on a limited fast, which continued even while he had minor symptoms. In a letter to the eminent chemist P. C. Ray, Gandhi explained his dietary problems: 
"You may have heard of my illness. It was a severe attack of dysentery. Though I seem to be convalescent, I am utterly prostrate with weakness. I can scarcely move out of my bed or even sit in it for any length of time. The great question is how to build up this broken-up body. I have abstained from milk and its products for several years and vowed to do so for life. I, therefore, need a substitute for milk and butter. Hitherto in my strength, I have found an excellent substitute in groundnuts, walnuts and such other nuts, but fats obtained from all these nuts are too strong for my delicate stomach. I need an exact vegetable substitute for ghee and milk. I have tried kopra milk and almond milk before now. The physiological action of these milks is totally different from that of cow's milk. Do you know any vegetable substitutes for ghee or butter and for milk?" (Gandhi to P C Ray, 27 August 1918; see also Gandhi to Millie Polak, 31 August 1918)

So, his fundamental philosophy remained that the basis of dietetics (in his case, vegetarianism) is not physical but moral and, like any moral thing (politics included), required personal obedience. Following proper dietetic habits and vegetarianism strictly depends upon the greater moral force of personal obedience. In India, the daily routine of Gandhi included meals mostly comprised of vegetarian items, besides grains, soya beans, pulses, edible roots, tubers and green leaves and included fruits, both fresh and dry (nuts like almonds, pistachio and walnuts) (Gandhi 1959: 1) and goat milk or cream milk. For rice and starch, which he detested, but as mentioned earlier, found red rice or unpolished rice and Gur to be suitable for the country teeming with poverty and malnutrition. He also advised that an individual should take not more than three meals a day; even two meals per day is sufficient for the sustenance of the body.

In each of his experiments, the objective was to bring out two basic things: (1) to systematise dietetics in such a fashion that would ensure the proper functioning of the body organs and eliminate the chances of unnecessary invitations for physical and mental stress, and (2) to organise dietetics so that it would become cheaper and economical. To address the objectives mentioned above, he also believed that each case has merit and hence needs to re-design the general formulation according to their region, availability of leaves, vegetables, and fruits, keeping all the vitamins, proteins, and 
proteins mineral intakes in mind. Nature has provided ample resources to feed and sustain human beings. Hence all food must be sourced from nature, avoiding any form of artificial preparation.

\section{Conclusion}

Gandhi was undoubtedly the modern-day influencer for unpolished fibrous food and the utility of raw food for sustainable development. Over time, his philosophy changed from identifying vegetarianism with effeminacy to a national masculine ideal to a political, moral and spiritual principle. Though Gandhi believed in vegetarianism till the end, he did not force anyone into his beliefs, thus when asked about the individual's freedom for the choice of food, he replied, unhesitatingly that, "Proof of the pudding is in the eating; let everyone do the experiments for himself" ${ }^{\mathrm{xv}}$. For this, he maintained, after years of experiment and research, that there cannot be a fixed dietetic rule for all constitutions. Each demands particular merit regarding dietetics. However, the cardinal principle remains the same: (a) consumption of vegetables, fruits and pulses; (b) use of a minimum quantity of starch and salt; (c) dietetics for providing energy, vitality and supplements with the normal function of the body organs; (d) consumption of food for the relative freedom of women from the clutches of food preparation; (e) necessity to follow proper dietetics to achieve specific objectives in life, as food intake is the expression of the individual's inner-self. One must follow these to shadow his/her experiments with food and food habits. Hence, Gandhi's experiment with diet not only harnessed, literally and figuratively, a specific political system but also expanded the women's horizon obliterating the bondage of preparation of food. In the Indian family system, women are entrusted with the preparation of food and other household chores. He believed that if women were done away with this responsibility, they could effectively participate in the freedom movement like their male counterparts. This political strategy adopted by Gandhi synchronised the personal as political and vice-versa; the dietetics was a part of the complete synchronisation of his political/personal dichotomy.

Gandhi's dietetics converged at a point of personal quest and political, public involvement. It would need further research to identify how his dietetics paved the way for this personal and political 
convergence. Gandhi moved away from the 1891 model of the Indian shepherd of being the British counterpart of masculinity. Rather than the body, the mind and the spirit became important in the Gandhian philosophy of dietetics. He even thought of India having a 'national' character in the matter of dietetics. He knew very well that it was almost impossible to achieve a particular feat due to the food habits of different regions of India. Each region has its unique taste that cannot be taken daily, but he suggested that if we exchange our food habits, simplify our tastes, and produce healthy dishes, we would become national rather than remaining provincial in food and food habits. There are no combinations in different states but different styles in the same province among the various communities. We need to carefully study different castes, denominations, and different communities in different provinces to prepare such typical dishes for ordinary people. Thus, we see the vision of a man who tried to establish dietetics as a body of scientific knowledge to construct consciousness of nationalism among the common people of India. Some simple thoughts are envisioned through the experiments in his own life; sometimes for achieving Satya, sometimes for achieving Swaraj; sometimes to build a nation within the diverse communities like that of India; sometimes to keep the physical and mental well-being of the individual.

For Gandhi, these concepts regarding dietetics and all his other practices were not ideologically developed. Like his other ideas, the idea of dietetics grew by questioning his presuppositions and that he had to figure hard to attain them as something meaningful to his life and praxis. These notions arose from experiences of personal as well as the expectation of social, and it is this shift that is significant for further analysis on the idea of dietetics. The shift from personal to social in cases of dietetics may not be as prominent as Gandhi's other political practices. However, they are significant enough to be a potent weapon to develop the means (Ahimsa, Satyagraha, brahmacharya) to achieve the ultimate objective (Satya). They have been nuanced enough by exploring internal debates and contradictions constituting the relationship between personal and social. Hence, Gandhi's knowledge will be a steppingstone for augmenting such research because of the vast literature, both by Gandhi and 
regarding Gandhi, which is mostly untouched. In the context of attempts in today's world to limit food choices determined by faith or religion, Gandhi's stand that one's diet should never be based on faith but should be reasoned out by individual requirements is quite inspirational. Gandhi wrote (1927: 257) 'to sum up all religion in terms of diet, as is often done in India, is as wrong as disregard all restraint regarding diet and give full reins to one's appetite'.

Food gave him a political cause to protest, right from his years in London and later South Africa, as he linked his quest for vegetarianism with several radical causes and his emerging concept of ahimsa or non-violence. Just as his techniques of protest and negotiation changed in politics, so made his choices and vows in food and dietary practice undergoing compromises and negotiations with the self. The fact that Gandhi abjured salt entirely from his diet at one point and again started taking moderate amounts can also be a pointer to the choice of salt as the weapon of protest in his Dandi March. From his dietary experiments, Gandhi understood the indispensability of salt, more so for hard-working people in India. Just as Gandhi strategised his food choices and portion control by adhering to vegetarianism to the tee, but with several changes and turnarounds in his dietary practice, he used strategies, albeit different ones, to negotiate the British, adhering to non-violence at its basics. Just like his dietary experiments, his political experiments, too, were steps towards self-restraint. Just as his politics was his spirituality, his food choices were his connection with the inner self. Fasting was, in essence, an act of restricting, as was the art of non-violence, a supreme lesson in restraint.

\section{References}

Banerjee, S. 2020. Tracing Gandhi: Satyarthi to Satyagrahi. London and Shimla: Routledge and Indian Institute of Advanced Study.

Bhargava, Balram \& Kant Rajni 2019. Health File of Mahatma Gandhi: His Experiments with Dietetics and Nature Cure, Indian Journal of Medical Research, Volume-149, Issue Number-7, p.5. 
Brown, J. 1996. 'Perspectives and Prospects'., in Gandhi and South Africa: Principles and Politics, eds. Judith Brown and Martin Prozesky, New York: St. Martin's Press.

Counihan, C. \& Esterik, V. P. 2013. Food and Culture: A Reader. Routledge: New York.

Gandhi, M.K. 1957. Moral Basis of Vegetarianism. Ahmedabad: Navajivan Publishing House. 1955. Ashram Observances in Action. Ahmedabad: Navajivan Publishing House. 1949. Diet and Diet Reforms. Ahmedabad: Navajivan Publishing House. 1927. The Story of My Experiments with Truth: An Autobiography. Ahmedabad: Navajivan Publishing House. 1920. Young India. Ahmedabad: Navajivan Publishing House.

Greenebaum, Jessica. 2012. 'Veganism, Identity and the Quest for Authenticity.' Food, Culture and Society 15 (1): 129-144. DOI: 10.2752/175174412X13190510222101

Iyer, R. 1973. The Moral and Political Thought of Mahatma Gandhi. Oxford: Oxford University Press.

Kapoor, P. 2017. Gandhi: An Illustrated Biography. New Delhi: Thames and Hudson.

Lax, J. B. \& M, A. G. 2020. 'The perceived masculinity of meat: development and testing of a measure across social class and gender.' Food, Culture \& Society Vol. 23 (3): 416-426 DOI: $10.1080 / 15528014.2020 .1741068$

Rollo, M. 1972. Power and Innocence: A Search for the Sources of Violence, New York: Delta. Rothgerber, H. 2013. 'Real Men Don't Eat (Vegetable) Quiche: Masculinity and the Justification of Meat Consumption." Psychology of Men \& Masculinity 14 (4): 363-375. doi:10.1037/a0030379.

Roy, P. 2002 'Meat Eating, Masculinity, and Renunciation in India: A Gandhian Grammar of Diet.' Gender \& History, 14 (1), 62-91.

Ruby, M. B. and Heine, S. J. 2011. 'Meat, Morals, and Masculinity.' Appetite 56 (2): 447-450 Doi: 10.1016/j.appet.2011.01.018. 
Mehta, V. 1977. Mahatma Gandhi and His Apostles. New York: Viking Press.

Parekh, B. 1995. Gandhi's Political Philosophy: A Critical Appreciation. Delhi: Ajanta.

Parel. Anthony J. (Ed.) 1997. Gandhi: Hind Swaraj and Other Writings. New Delhi: Foundation Books.

Publications Division. 2017. The Collected Works of Mahatma Gandhi (CWMG) Vols. 1-100 (1958-1994). New Delhi: Government of India.

Polak, H S L, H N Brailsford and Lord P-Lawrence. 1949. Mahatma Gandhi. London: Odhams Press.

Roy, R. (Ed.) 1986. Contemporary Crisis and Gandhi, Delhi: Discovery Publishing House

Slate, N. 2019. Gandhi's Search for the Perfect Diet: Eating with the World in Mind. Washington: University of Washington Press.

Sethi, J D. 1979. Gandhian Values and 20th Century Challenges. New Delhi: Publication Division, Government of India.

Tikedar, S.R. 1971. Epigrams from Gandhiji. New Delhi: Government of India Publications Division Ministry of Information and Broadcasting.

\section{End Notes}

\footnotetext{
' In India he is known by various names like Bapu, Bapuji, Mahatma, Mahatma Gandhi, M.K. Gandhi and various other. i" Ahimsa or non-violence is at the core of his ideas, which can be briefly described as the way of life which denounces any form of violence be it physical, verbal, in thoughts or deeds. Ahimsa originated from the Sanskrit root san [verb], which means to kill. The form himsa means "desirous to kill"; the prefix $a$-is a negation. So, $a$-himsa signifies "lacking any desire to kill". Literally interpreted, ahimsa means to be devoid of harm; to be completely harmless, not only to oneself and others, but to all living beings. Following the literal meaning the word is the opposite of himsa, "violence" which is to hurt the vitalities [pranas], through vibration due to the passions, which agitate mind, body, or speech. Tattvarthadhigama Sutra vii:13.

iii Another philosophical and political narrative of Gandhi, which in simple terms can be described as the passion or quest for knowing the ultimate, i.e., truth. This is the very reason he stated in many of his commentaries in Gujarati or in English or Hindi that Ahimsa is the bedrock of Satygraha. In his autobiography 'The Story of My Experiments with Truth,' he mentioned that the word was originally coined by Maganlal Gandhi as 'Sadagraha' (Sat=truth, Agraha= firmness but to make it formidable he changed the term into Satyagraha).

${ }^{i v}$ https://www.downtoearth.org.in/news/health/gandhi-fitness-freak-and-champion-of sustainable-food-63749.

${ }^{v}$ A weekly newspaper published by Gandhi, this was one among many newspapers like India Opinion from South Africa [in English], Golden Number from India [in English] Navjivan from India [both in Gujrati and Hindi], Harijan Sevak from India [in Hindi], Harijan Bandhu from India [in Gujrati] and Harijan from India in English.

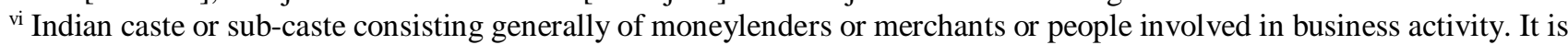
also important to note that not all mercantile classes are Baniyas. These sorts of sub-castes are generally found in northern or western part of India.
} 
vii Gandhi's family in Gujarat hailed from the Vaishnava sect of Hindu religious order, which was traditionally prone and believed in vegetarianism. Being a staunch opponent of eating any sort of meat, eating or even bringing in cooked meat item was a taboo and strictly prohibited under religious, social and ethical code of conduct.

viii It was in a journal published by the society where the entire story of his early transformation can be found [Gandhi 1949; 9].

${ }^{\text {ix }}$ Gandhi learned violin, took elocution classes, attempted ballroom dance and even altered his clothes, which were distinct marks of British identity apart from language and belief in rule of law.

${ }^{x}$ The author has consciously used the subject in lieu of 'citizens' keeping the colonial period in mind.

${ }^{x i}$ https://www.theatlantic.com/entertainment/archive/2019/02/gandhis-raw-food-diet/582721. Accessed on 20.11.2020

xii Later on the advice of doctors, in 1829, he left this method of consumption of raw food.

xiii Gandhi to Ranchhodlal Patwari, 9 September 1918; see also Gandhi to C F Andrews, 29 August 1918.

xiv https://www.huffingtonpost.in/entry/mahatma-gandhi-diet_1_5cb6021fe4b082aab08d3954. Accessed on 20.11.2020

${ }^{\mathrm{xv}}$ https://www.mkgandhi.org/health/diet_reform/21rice.html. Accessed on 20.11.2020 